\title{
EFFECT OF GREEN MANURING WITH MERREMIA AEGYPTIA ON AGRO- ECONOMIC EFFICIENCY OF RADISH PRODUCTION ${ }^{1}$
}

\author{
RENATO LEANDRO COSTA NUNES ${ }^{2 *}$, FRANCISCO BEZERRA NETO ${ }^{3}$, JAILMA SUERDA SILVA DE LIMA ${ }^{3}$, \\ ARIDÊNIA PEIXOTO CHAVES ${ }^{3}$, JOSIMAR NOGUEORA DA SILVA ${ }^{4}$, ELIZÂNGELA CABRAL DOS SANTOS ${ }^{3}$
}

\begin{abstract}
The introduction of new crops in northeastern Brazil, associated with the use of the green manure, can become an alternative for family farmers. Thus, the objective of this work was to determine the effect of green manuring with $M$. aegyptia L. on the agro-economic efficiency of radish production. The experimental design was a randomised complete block with four treatments and five replicates; the treatments were composed of four doses of M. aegyptia $\left(20,35,50\right.$ and $65 \mathrm{tha}^{-1}$ on a dry basis) incorporated into the soil in three cropping periods. In radish plants, we evaluated plant height, fresh and dry mass of shoots, total and commercial productivity of roots, productivity of scrap roots, dry mass of roots and root diameter. The economic indicators gross income, net income, rate of return and profit margin were used to evaluate the agro-economic efficiency of the system. The maximum agronomic efficiency was reached with a commercial root productivity of $7.86 \mathrm{t} \mathrm{ha}^{-1}$ and the addition of $49.29 \mathrm{t} \mathrm{ha}^{-1}$ of green manure. The maximum economic efficiency was obtained with a net income of $11,955.46 \mathrm{R} \$ \mathrm{ha}^{-1}$ when a green manure dose of $46.00 \mathrm{t} \mathrm{ha}^{-1}$ was added. The use of $M$. aegyptia as green manure is economically viable in the production of radish in the semi-arid region of Northeast Brazil.
\end{abstract}

Keywords: Raphanus sativus. Brazilian semi-arid. Green manure.

\section{EFEITO DA ADUBAÇÃO VERDE COM MERREMIA AEGYPTIA NA EFICIÊNCIA AGROECONÔMICA DA PRODUÇÃO DE RABANETE}

\begin{abstract}
RESUMO - A introdução de novas culturas no nordeste do Brasil associada com o uso da adubação verde pode tornar-se uma alternativa para os agricultores familiares. Desta forma, o objetivo deste trabalho foi determinar o efeito da adubação verde com $M$. aegyptia $\mathrm{L}$. na eficiência agroeconômica da produção de rabanete. $\mathrm{O}$ delineamento experimental foi em blocos casualizados com quatro tratamentos e cinco repetições; os tratamentos foram compostos por quatro doses de M. aegyptia $\left(20,35,50\right.$ e $65 \mathrm{t}^{-1}{ }^{-1}$ em base seca) incorporadas ao solo em três períodos de cultivos. Em plantas de rabanete foram avaliadas altura de plantas, massa fresca e seca da parte aérea, produtividade de raízes total e comercial, produtividade de raízes refugo, massa seca de raízes e diâmetro de raízes. Os indicadores econômicos renda bruta, renda líquida, taxa de retorno e índice de lucratividade foram utilizadas para avaliar a eficiência agroeconômica do sistema. A eficiência agronômica máxima foi alcançada com a produtividade comercial de raízes de $7,86 \mathrm{t} \mathrm{ha}^{-1}$, e adição de 49,29 $\mathrm{t} \mathrm{ha}^{-1}$ do adubo verde. A eficiência econômica máxima foi obtida com um lucro líquido de 11.955,46 R $\$ \mathrm{ha}^{-1}$, quando adicionada a dose de adubo verde de $46,00 \mathrm{tha}{ }^{-1}$ de adubo verde. O uso de $M$. aegyptia como adubo verde é economicamente viável na produção de rabanete na região semiárida do Nordeste do Brasil.
\end{abstract}

Palavras-chave: Raphanus sativus. Semiárido brasileiro. Adubação verde.

\footnotetext{
${ }^{*}$ Corresponding author

${ }^{1}$ Received for publication in 06/05/2020; accepted in 08/17/2020.

Paper extracted from the doctoral thesis work of the first author.

${ }^{2}$ Teaching Department, Instituto Federal de Educação, Ciência e Tecnologia do Ceará, Limoeiro do Norte, CE, Brazil; renatoleandro.ce@hotmail.com - ORCID: 0000-0001-5792-2442.

${ }^{3}$ Department of Agronomic and Forestry Sciences, Universidade Federal Rural do Semi-Árido, Mossoró, RN, Brazil; bezerra@ufersa.edu.br - ORCID: 0000-0001-9622-206X, jailma@ufersa.edu.br - ORCID: 0000-0001-7584-592X, aridenia.peixoto@hotmail.com - ORCID: 0000-0002-2184-2536, elizangelacabral@ufersa.edu.br - ORCID: 0000-0002-7074-3147.

${ }^{4}$ Secretariat of Agriculture and Water Resources, Belém do Brejo do Cruz, PB, Brazil; josimar2160@hotmail.com - ORCID:0000-00019508-5526.
} 


\section{INTRODUCTION}

Radish is a tuberous vegetable and rich in minerals such as potassium, sodium, calcium, phosphorus, magnesium, with high levels of vitamins $\mathrm{C}$ and $\mathrm{A}$. Although this crop demands a low level of soil fertility, green manuring positively impacts its development and productivity (SILVA et al., 2016).

Among other benefits, the practice of green manuring can contribute to meeting the nutritional needs of the crop. In addition, it preserves, restores and increases the amount of organic matter and the soil nutrient contents (BATISTA et al., 2016), favouring the sustainable use of physical, chemical and biological factors.

The effect of green manuring on a crop of economic interest depends, among other factors, on the species used, the management carried out with the vegetal biomass in relation to its cut and the time of incorporation into the soil, on the interval between the incorporation and sowing of the crop, on the natural fertility of the soil and the climatic conditions and on the interactions among these factors (ALCÂNTARA et al., 2000). The green manure collecting stage also plays an important role, especially if peak nitrogen accumulation is reached by the bloom stage in some species.

In the semi-arid region of Northeastern Brazil, some studies have focused on the reduction of the environmental impact and the optimization of the efficiency of vegetable production systems with the use of green manure from spontaneous species of the Caatinga biome (PEREIRA et al., 2016; SILVA et al., 2016; SOUZA et al., 2017; VIEIRA et al., 2018).

Among such species, $M$. aegyptia is a spontaneous plant of the family Convolvulaceae, native to the Brazilian Northeast. It can reach a green phytomass productivity of $36 \mathrm{t} \mathrm{ha}^{-1}$, presenting itself as an excellent green manure plant (BEZERRA NETO et al., 2011). This practice can be of great value to the family farmers of the semi-arid region as a way of minimising production costs (SILVA et al., 2016).

Bezerra Neto et al. (2014), studying the agroeconomic optimisation of carrot production systems fertilised with different doses of $M$. aegyptia, observed that the viability of the crop increased by $36.46 \%$ when the dose of $13 \mathrm{t} \mathrm{ha}^{-1}$ of green manure was incorporated into the soil, in comparison with a smaller incorporated dose of $7.5 \mathrm{t} \mathrm{ha}^{-1}$. Oliveira et al. (2017), evaluating the viability of polycultures of arugula-carrot-coriander fertilised with $M$. aegyptia under different population densities, verified that the best agronomic performance of the polycultures was obtained with $18.21 \mathrm{t} \mathrm{ha}^{-1}$ of green manure incorporated into the soil. This response was about 2.61 times greater than the value obtained in relation to the lower dose of $7.5 \mathrm{t} \mathrm{ha}^{-1}$ of green manure.
Considering other cultures, Sousa et al. (2018), studying the agro-economic performance of beet cultivated in association with cowpea under different doses of $M$. aegyptia, observed a higher performance at a dose of $55 \mathrm{t} \mathrm{ha}^{-1}$ of green manure added to the soil. This yield was $25.08 \%$ higher compared to that obtained with the lowest dose of $10 \mathrm{t} \mathrm{ha}^{-1}$ of green manure.

In this sense, we evaluated the effect of green manuring with $M$. aegyptia on the agro-economic efficiency of radish production in the semi-arid region of northeast Brazil.

\section{MATERIALS AND METHODS}

Three experiments were conducted in different areas of the Experimental Farm 'Rafael Fernandes', located in the Alagoinha district, $20 \mathrm{~km}$ from Mossoró-RN (5 ${ }^{\circ} 11^{\prime} 31^{\prime \prime} \mathrm{S}$ and $37^{\circ} 20^{\prime} 40^{\prime \prime} \mathrm{W}$, $18 \mathrm{~m}$ above sea level) in different cropping of the years 2015, 2016 and 2017, but specifically between the months of July and December of the dry season. The climate of the region is semi-arid and, according to the Köppen climate classification scheme, designated as 'BShw', dry and very hot, with two seasons: a dry season, which usually comprises the months of June to January, and a rainy season from February to May (ALVARES et al., 2014), with an annual mean precipitation of around $685.3 \mathrm{~mm}$.

Figure 1 shows the maximum, medium and minimum temperatures and the relative humidity levels in the cropping periods of 2015, 2016 and 2017.

According to Rêgo et al. (2016), the soil of the experimental areas is classified as typical Distrophic Red Argisol; sand, silt and clay contents are shown in Table 1.

Prior to the installation of the field experiment, soil samples from the experimental area in each cropping period were collected and sent for analysis; the results are presented in Table 2.

The amount of total $\mathrm{N}$ was determined by the Kjeldahl method. The $\mathrm{pH}$ and EC levels were analysed using a $\mathrm{pH}$ meter and a conductivity meter, respectively. Carbon was determined by dichromatometry. For the $\mathrm{P}$ and $\mathrm{K}$ contents, the Mehlich extractor ( $\mathrm{HCl} 0.05 \mathrm{~mol} \mathrm{~L}^{-1} \mathrm{H}_{2} \mathrm{SO}_{4}+0.025$ mol L ${ }^{-1}$ ) was applied, using colorimetry and flame photometry, respectively. The $\mathrm{Na}^{+}$level was determined in dilute hydrochloric acid solution via flame spectrophotometry. The $\mathrm{Ca}^{2+}$ and $\mathrm{Mg}^{2+}$ contents were obtained by extraction with $1 \mathrm{~mol} \mathrm{~L}^{-1}$ $\mathrm{KCl}$ and quantified by atomic absorption spectrophotometry and titration with $0.01 \mathrm{~mol} \mathrm{~L}^{-1}$ $\mathrm{NaOH}$, respectively. The $\mathrm{Cu}, \mathrm{Fe}, \mathrm{Mn}$ and $\mathrm{Zn}$ contents were quantified by the atomic absorption spectrometry method (EMBRAPA, 2009). 

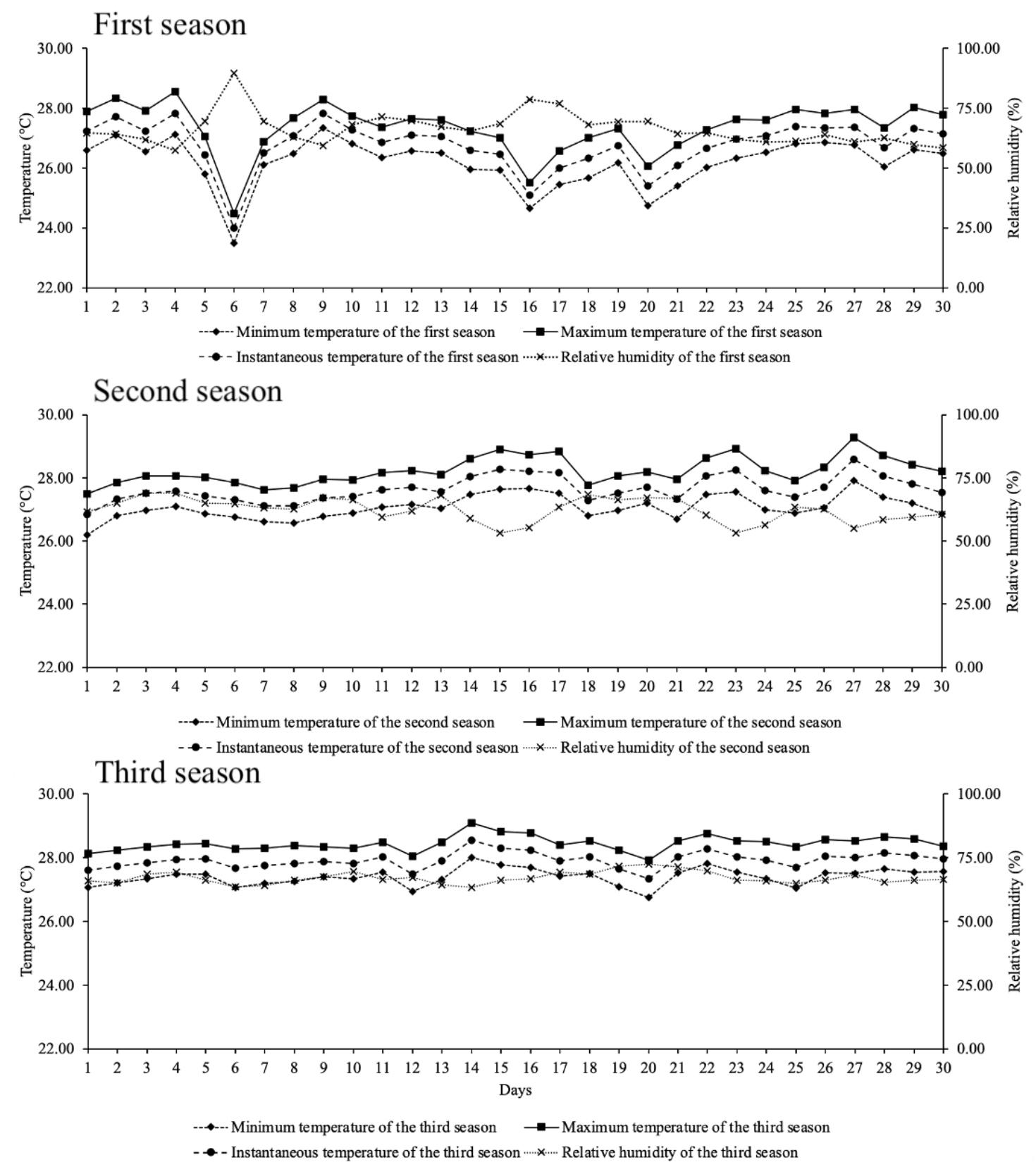

Figure 1. Climatic data provided by the NIMET (National Institute of Meteorology) for the cropping periods in the summers of 2015, 2016 and 2017 in Mossoró-RN.

Table 1. Physical attributes of the profiles of the Alagoinha district soils where the experiments were performed.

\begin{tabular}{|c|c|c|c|c|}
\hline \multirow{3}{*}{$\begin{array}{l}\text { Depth * } \\
\text { (cm) }\end{array}$} & Coarse sand & Fine sand & Silt & Clay \\
\hline & \multicolumn{4}{|c|}{-----------------g kg ${ }^{-1}$---------------- } \\
\hline & \multicolumn{4}{|c|}{ Soil profile of the Typical dystrophic red Ultisol } \\
\hline A $(0-22)$ & 729 & 192 & 20 & 59 \\
\hline $\mathrm{AB}(22-47)$ & 580 & 262 & 27 & 131 \\
\hline BA (47-107) & 502 & 238 & 42 & 219 \\
\hline Bt1 (107-183) & 487 & 239 & 48 & 226 \\
\hline Bt2 $\left(183-233^{+}\right)$ & 419 & 165 & 48 & 369 \\
\hline
\end{tabular}

*Horizons: A (0-22 cm); AB (22-47 cm); BA (47-107 cm); Bt1 $(107-183 \mathrm{~cm})$ and Bt2 $(183-233 \mathrm{~cm})$.

Rev. Caatinga, Mossoró, v. 33, n. 4, p. 964 - 973, out. - dez., 2020 
R. L. C. NUNES et al.

Table 2. Results of the chemical analyses of the soils prior to incorporation of $M$. aegyptia in the three cropping periods.

\begin{tabular}{|c|c|c|c|c|c|c|c|c|c|c|c|c|}
\hline \multirow{2}{*}{ Cropping periods } & \multirow{2}{*}{$\begin{array}{c}\mathrm{pH} \\
\text { (water) }\end{array}$} & \multirow{2}{*}{$\begin{array}{c}\mathrm{EC} \\
\mathrm{ds} \mathrm{m}^{-1}\end{array}$} & \multirow{2}{*}{$\begin{array}{c}\mathrm{OM} \\
\mathrm{g} \mathrm{kg}^{-1}\end{array}$} & $\mathrm{P}$ & $\mathrm{K}$ & $\mathrm{Na}$ & $\mathrm{Ca}$ & $\mathrm{Mg}$ & $\mathrm{Cu}$ & $\mathrm{Fe}$ & $\mathrm{Mn}$ & $\mathrm{Zn}$ \\
\hline & & & & \multicolumn{3}{|c|}{$\mathrm{mg} \mathrm{dm}^{-3}$} & \multicolumn{2}{|c|}{$\mathrm{cmol}_{\mathrm{c}} \mathrm{dm}^{-3}$} & \multicolumn{4}{|c|}{$\mathrm{mg} \mathrm{dm}^{-3}$} \\
\hline 2015 & 7.46 & 1.77 & 3.64 & 63.3 & 60.0 & 17.0 & 2.09 & 0.58 & 0.19 & 2.03 & 10.43 & 6.21 \\
\hline 2016 & 7.10 & 0.55 & 3.51 & 40.2 & 61.8 & 16.9 & 2.57 & 0.61 & 0.21 & 2.53 & 10.94 & 7.41 \\
\hline 2017 & 6.60 & 0.10 & 3.65 & 34.2 & 69.2 & 19.0 & 3.10 & 0.80 & 0.29 & 2.86 & 11.40 & 7.35 \\
\hline
\end{tabular}

$\mathrm{N}$ - Nitrogen; pH - Hydrogen ionic potential; EC - Electrical conductivity; OM- Organic matter; P - Phosphorus; K Potassium; Na - Sodium; Ca - Calcium; Mg - Magnesium; $\mathrm{Cu}$ - Copper; Fe - Ferro; Mn - Manganese and Zn - Zinc.

The M. aegyptia material was collected in Mossoró-RN and crushed in a conventional shredder machine, obtaining fragments with a length of 2 to 3 $\mathrm{cm}$; the material was dried in the sun until reaching the condition of hay ( $10 \%$ of humidity). The nutrient levels of the dried material were determined and are shown in Table 3.

Table 3. Macro and micronutrient contents in M. aegyptia biomass and $\mathrm{C} / \mathrm{N}$ ratio in the three cropping periods.

\begin{tabular}{ccccccc}
\hline \multirow{2}{*}{ Cropping periods } & \multicolumn{4}{c}{ Macronutrient contents in the green manure $\left(\mathrm{g} \mathrm{kg}^{-1}\right)$} & \multicolumn{2}{c}{$\mathrm{C} / \mathrm{N}$} \\
\cline { 2 - 6 } & $\mathrm{N}$ & $\mathrm{P}$ & $\mathrm{K}$ & $\mathrm{Ca}$ & $\mathrm{Mg}$ & \\
\hline 2015 & 11.4 & 2.4 & 10.5 & 8.3 & 9.8 & $25: 1$ \\
2016 & 14.8 & 2.5 & 12.0 & 8.1 & 8.2 & $25: 1$ \\
2017 & 15.3 & 4.0 & 15.7 & 9.3 & 7.0 & $25: 1$ \\
\hline
\end{tabular}

For analysis of $\mathrm{P}$ and $\mathrm{K}$, we used extracts obtained through digestion with sulphur. Nitrogen was quantified by the Kjeldahl semi-micro method, phosphorus by yellow vanadium, and potassium via emission flame spectrometry.

The calcium and magnesium contents were quantified by the atomic absorption spectrometry method (EMBRAPA, 2009). The $\mathrm{C} / \mathrm{N}$ ratio was obtained by dividing the total carbon content by the total $\mathrm{N}$ content in each green manure sample. The total carbon content was determined via combustion in a muffle at a temperature of $550^{\circ} \mathrm{C}$ (SILVA, QUEIROZ, 2002).

The experimental design was a randomised complete block design with four treatments and five replicates. The treatments consisted of four doses of $M$. aegyptia incorporated into the soil $(20,35,50$ and $65 \mathrm{t} \mathrm{ha}^{-1}$ on a dry basis) in three different cropping periods. The radish cultivar sown was cv. Crimson Giant, recommended for cultivation in the semi-arid region of the Brazilian Northeast. Crop cultivation was established in plots of six rows, where the lateral rows were used as the borders.

The total area of each plot was $1.44 \mathrm{~m}^{2}$. The harvest area was $0.80 \mathrm{~m}^{2}(1.00 \mathrm{~m} \times 0.80 \mathrm{~m})$, containing 40 radish plants (LINHARES et al., 2017) with a row spacing of $0.20 \mathrm{~m}$ and a within-row spacing of $0.10 \mathrm{~m}$ (Figure 2), with a density population of 350,000 plants per hectare (BATISTA et al., 2013). Approximately $30 \%$ of the area are considered traffic area (formed by corridors and roads).

Soil preparation consisted of ploughing and harrowing, followed by lifting the beds. Prior to the field work, the planting beds were subjected to a solarisation period of 45 days.

The green manure was incorporated 20 days prior to sowing in the $0-20-\mathrm{cm}$ soil layer in each cropping period. After incorporation of M. aegyptia, daily irrigations were carried out in two shifts to increase microbial activity and to facilitate organic matter mineralisation. Direct sowing in the respective years was carried out on July 12, 2015, September 19, 2016 and November 21, 2017, adopting a depth of $2 \mathrm{~cm}$. After seedling emergence, thinning was performed after 7 days, leaving one plant per hole. Manual weeding was carried out when necessary.

During the experiments, the plots were irrigated daily with the use of a micro sprinkler system. The amount of water supplied was determined by the radish cultivation coefficient (initial $\mathrm{K}_{\mathrm{cr}}=0.7, \mathrm{~K}_{\mathrm{cr}}$ in development $=0.9$ and $\mathrm{K}_{\mathrm{cr}}$ final $=0.85) \quad($ ALLEN et al., 1998), with one irrigation shift daily from 8 to $10 \mathrm{~mm}$. Radish plant samples were harvested at 30 days after sowing.

For the samples, we recorded plant height, fresh and dry mass of shoots, total and commercial root productivity, productivity of scrap roots, dry root mass and root diameter. 


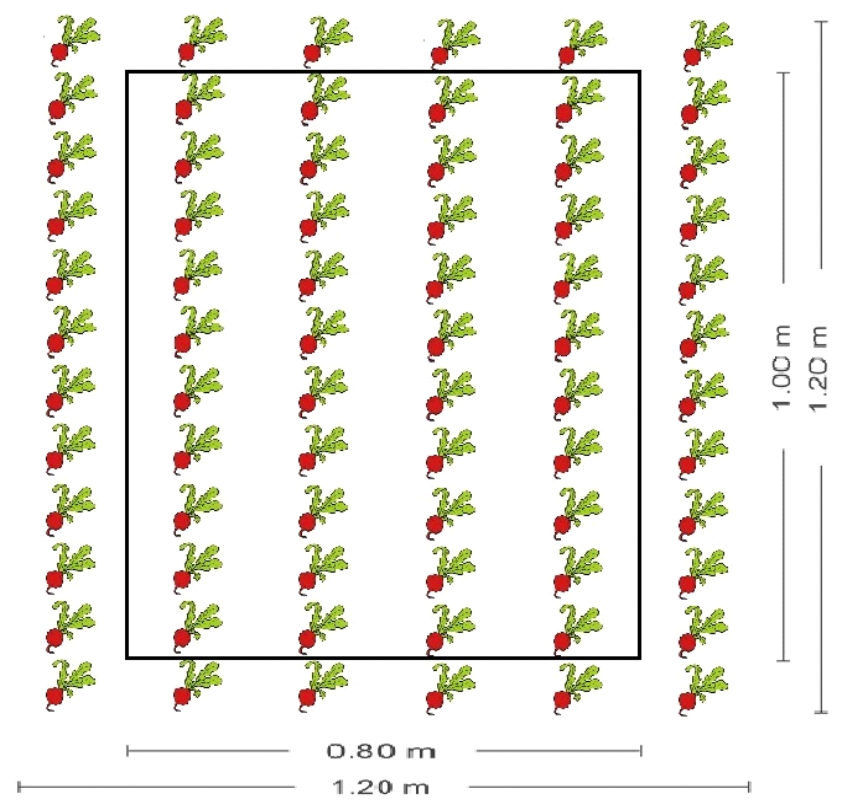

Figure 2. Detail of an experimental radish plot in the cropping periods of 2015, 2016 and 2017.

The indicators used for crop economic evaluation were the gross and net incomes, the rate of return and the profit margin. According to Beltrão et al. (1984), gross income was determined by multiplying the value of the yield obtained per hectare by the price paid to the producer in the region in the months of August 2015, October 2016 and December 2017. Net income of each treatment was obtained by subtracting from the gross income (RB) per hectare the total costs (TC) of production involved in obtaining the same. The rate of return was expressed by the ratio between gross income (RB) and total costs (TC), that is, TR $=\mathrm{RB} / \mathrm{TC}$, expressed as the amount of reals ( $R$ ) obtained by each invested real as a function of the applied treatments. In addition, the profit margin consisted of the ratio of net income (RL) to gross income (RB) and was expressed as a percentage.

Univariate analyses of variance for the randomised block design were used to evaluate the variables collected, and a regression analysis was used as a predictor of the behaviour of each variable as a function of the M. aegyptia tested doses, where a regression equation was estimated through the software Table Curve (JANDEL SCIENTIFIC, 1991). In addition, a joint analysis for the three cropping periods in each variable was performed through the SISVAR software (FERREIRA, 2011), where the Tukey test was used to compare the means between cropping periods.

\section{RESULTS AND DISCUSSION}

The results of the analysis of variance of the agro-economic variables evaluated for radish are presented in Table 4. Significant interactions were observed between cropping periods and doses of $M$. aegyptia incorporated into the soil for the variables plant height and fresh and dry shoot mass.

Table 4. F values for plant height (PH), fresh mass of shoots (FMS), dry mass of shoots (DMS), total (TPR) and commercial (CPR) root productivity, productivity of scrap roots (PSR), dry mass of roots (DMR), root diameter (RD), gross income (GI), net income (NI), rate of return (RR) and profit margin (PM) for different doses of M. aegyptia incorporated into the soil and for the different cropping periods.

\begin{tabular}{|c|c|c|c|c|c|c|c|c|c|}
\hline Sources of variation & DF & $\mathrm{PH}$ & FMS & DMS & TPR & CPR & PSR & DMR & $\mathrm{RD}$ \\
\hline Blocks (Periods) & 12 & $2.89^{* *}$ & $2.51^{*}$ & $1.88^{\mathrm{ns}}$ & $2.20^{*}$ & $2.27^{*}$ & $0.82^{\text {ns }}$ & $1.09^{\mathrm{ns}}$ & $2.28^{*}$ \\
\hline Cropping periods (P) & 2 & $30.55^{* *}$ & $155.93^{* *}$ & $278.35^{* *}$ & $91.32^{* *}$ & $92.50^{* *}$ & $4.30^{*}$ & $171.94^{* *}$ & $535.86^{*}$ \\
\hline Doses (D) & 3 & $14.08^{* *}$ & $19.99^{* *}$ & $16.20^{* *}$ & $5.06^{* *}$ & $3.69^{*}$ & $2.96^{*}$ & $0.86^{\text {ns }}$ & $4.56^{* *}$ \\
\hline $\mathrm{CV}(\%)$ & - & 8.78 & 17.00 & 12.98 & 20.76 & 24.62 & 44.93 & 19.44 & 5.58 \\
\hline & & \multicolumn{2}{|r|}{ GI } & \multicolumn{2}{|r|}{$\mathrm{NI}$} & \multicolumn{2}{|c|}{ RR } & \multicolumn{2}{|c|}{$\mathrm{PM}$} \\
\hline Doses (D) & 3 & & $12.03^{* *}$ & \multicolumn{2}{|r|}{$6.25^{* *}$} & \multicolumn{2}{|c|}{$6.27^{* *}$} & \multicolumn{2}{|c|}{$4.26^{*}$} \\
\hline $\mathrm{P} \times \mathrm{D}$ & 6 & & $0.95^{\mathrm{ns}}$ & \multicolumn{2}{|r|}{$1.28^{\mathrm{ns}}$} & \multicolumn{2}{|c|}{$2.08^{\mathrm{ns}}$} & \multicolumn{2}{|c|}{$1.73^{\mathrm{ns}}$} \\
\hline $\mathrm{CV}(\%)$ & - & & 20.65 & \multicolumn{2}{|r|}{21.98} & \multicolumn{2}{|c|}{31.86} & \multicolumn{2}{|c|}{27.75} \\
\hline
\end{tabular}

$* *=\mathrm{P}<0.01 ; *=\mathrm{P}<0.05 ; \mathrm{ns}=\mathrm{P} \geq 0.05$

Rev. Caatinga, Mossoró, v. 33, n. 4, p. 964 - 973, out. - dez., 2020 
Regarding the different doses of M. aegyptia within each cropping period, increasing responses of plant height were observed as a function of green manure doses, with maximum values of 15.82 and $20.44 \mathrm{~cm}$ for the doses of 50.84 and $53.49 \mathrm{t} \mathrm{ha}^{-1}$ in

A

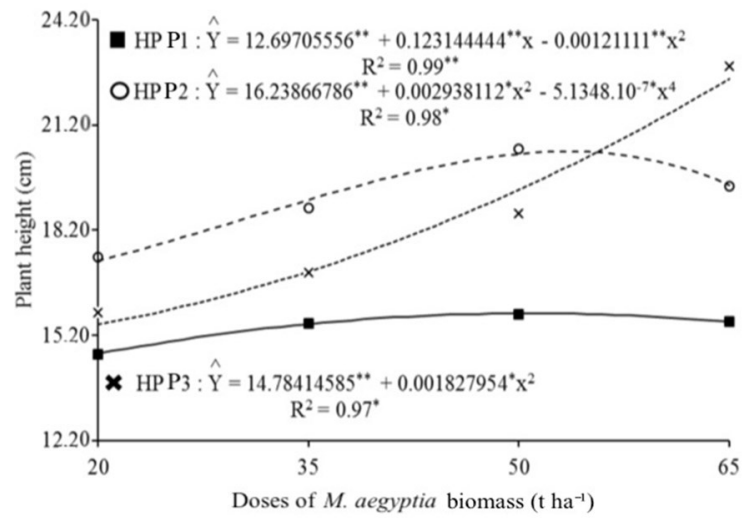

C

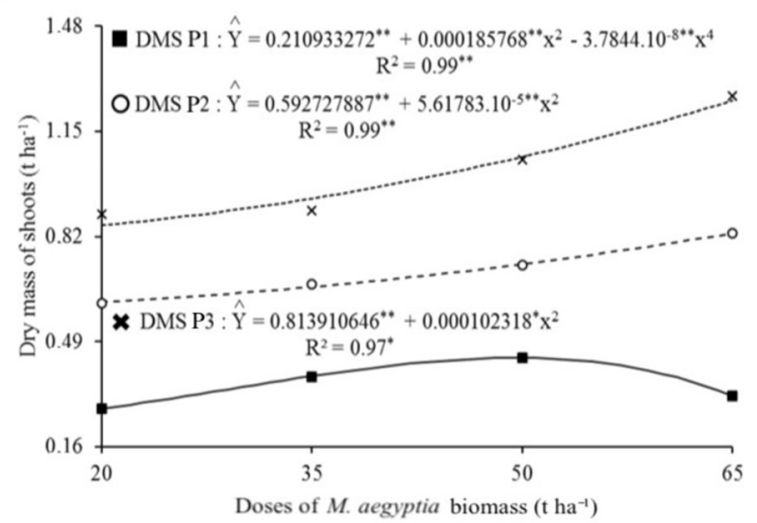

the first and second cropping period, respectively, followed by a decrease to the lowest dose (Figure 3A). On the other hand, a $6.99 \mathrm{~cm}$ increase in plant height was recorded from the lowest to the highest dose of M. aegyptia in the third cropping period.

B

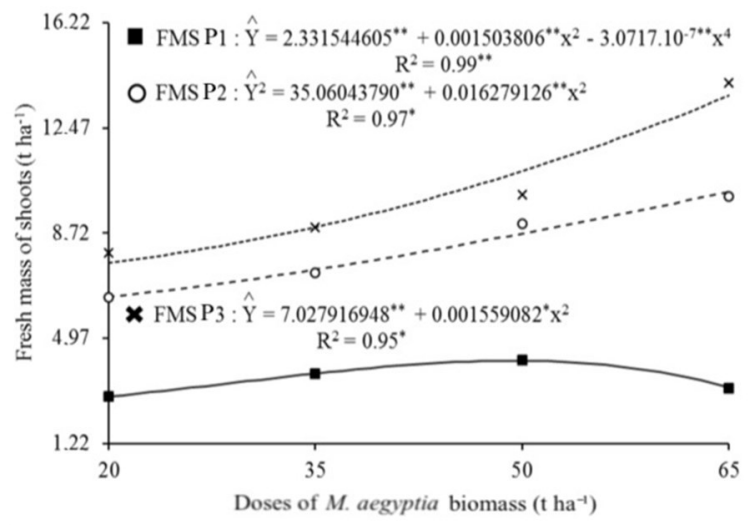

D

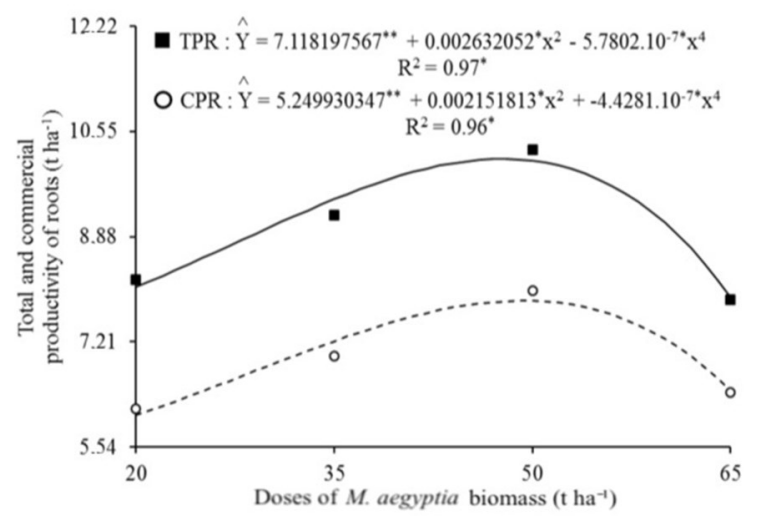

Figure 3. Plant height (A), fresh mass of shoots (B), dry mass of shoots (C), total productivity and commercial productivity of radish roots (D) at different cropping periods and doses of M. aegyptia incorporated into the soil.

An increase was also observed in the fresh mass of shoots in the first growing period with increasing doses of $M$. aegyptia reaching the maximum value of $4.17 \mathrm{t} \mathrm{ha}^{-1}$ for a dose of $49.47 \mathrm{t} \mathrm{ha}^{-1}$, followed by a decrease to the lowest dose (Figure 3B). However, in the fresh mass of shoots in the second and third periods, we only observed an increase of 3.74 and $5.97 \mathrm{t} \mathrm{ha}^{-1}$, respectively, between the lowest and the highest dose of green manure applied. A similar behaviour was observed for dry mass of shoots in the first growing period, where the maximum value found was of $0.44 \mathrm{t} \mathrm{ha}^{-1}$ for the dose of $49.54 \mathrm{t} \mathrm{ha}^{-1}$, followed by a decrease up to the lowest added dose (Figure 3C). Regarding the dry mass of shoots in the second and third period, we also observed only one increase of 0.21 and $0.40 \mathrm{t} \mathrm{ha}^{-1}$ between the lowest and highest doses of green manure.

The total and commercial productivity of roots also increased with increasing doses of $M$. aegyptia up to the maximum values of 10.11 and $7.86 \mathrm{t} \mathrm{ha}^{-1}$ for the doses of 47.72 and $49.29 \mathrm{t} \mathrm{ha}^{-1}$, respectively, and subsequently decreased (Figure 3D).

The behaviour of the variables $\mathrm{pH}, \mathrm{FMS}$ and DMS in the different cropping periods is due in part to the environmental conditions in the cropping periods of 2015, 2016 and 2017. Based on Figure 1, there was a greater variability among maximum, average and minimum temperatures as well as relative humidity in the first and second cropping period, resulting in a lower plant size. The same behaviour has also been observed by Nunes et al. (2018) when studying the intercropping of radish with cowpea in the same region. In this work, the performance of the agronomic variables presented in the different cropping periods in the semi-arid region is in agreement with the findings of Oliari et al. 
(2010), who evaluated the effect of temperature on the growth of radish plants and observed that under temperature stress, plants showed higher levels of height as well as total fresh and dry mass.

To obtain satisfactory yields, depending on the variety, in a relatively short period, the radish crop may need higher levels of nutrients (CASTRO et al., 2016), especially nitrogen and potassium (OLIVEIRA et al., 2014), which are necessary in greater quantity for root formation (ISLAM et al., 2011). In this way, the productive performance involving CPR, associated with the nutrients $\mathrm{N}$ and $\mathrm{K}$ can be related to the efficiency of the soil in terms of the degree of decomposition. According to Nunes et al. (2018), these decreases in radish productivities may be related to the velocity or degree of decomposition by viruses, bacteria, protozoan fungi and actinomycetes, whose activities may depend directly on the dose of green manure incorporated into the soil. This decrease can also be related to the fermentation of the material at the maximum incorporated dose or to the number of days required for the total mineralization of the incorporated material before sowing.

Regarding the productivity of scrap roots and dry mass of roots, an increasing behaviour of these variables was observed as a function of the doses of green manure incorporated into the soil, obtaining maximum values of 2.30 and $0.82 \mathrm{t} \mathrm{ha}^{-1}$, respectively, at the doses of 42.27 and $60.38 \mathrm{t} \mathrm{ha}^{-1}$, then decreasing up to the last added dose (Figure $4 \mathrm{~A}$ ). For root diameter, an increase of $0.37 \mathrm{~cm}$ was recorded between the lowest and the highest dose of the green manure (Figure 4B). Comparing the maximum values of $2.30 \mathrm{tha}^{-1}$ of PSR at the dose of $42.27 \mathrm{tha}^{-1}$ with the values of $2.24 \mathrm{t} \mathrm{ha}^{-1}$ of PSR with the addition of $49.29 \mathrm{t} \mathrm{ha}^{-1}$ of $M$. aegyptia, in the commercial productivity of radish roots, we would obtain a reduction of $2.60 \%$ of scrap roots with the dose of maximum agronomic efficiency.
$\mathbf{A}$

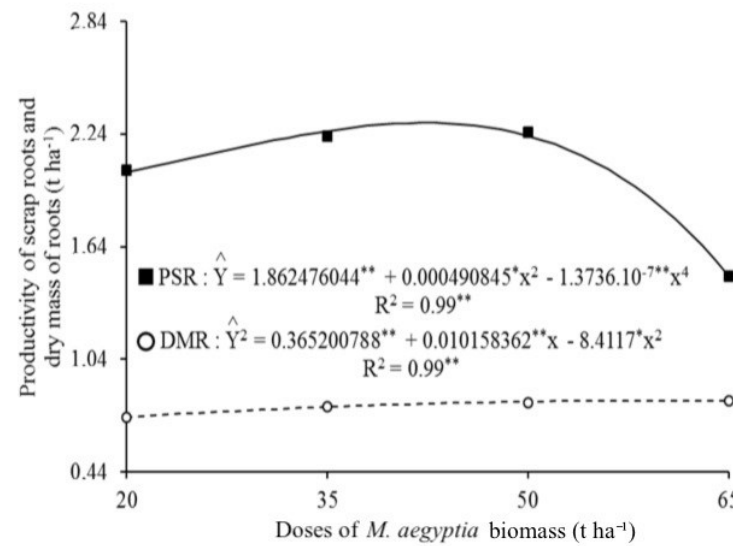

C

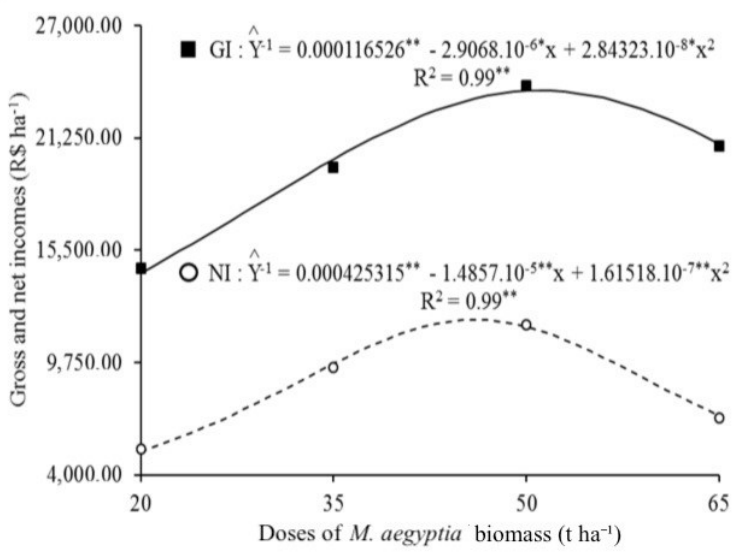

B

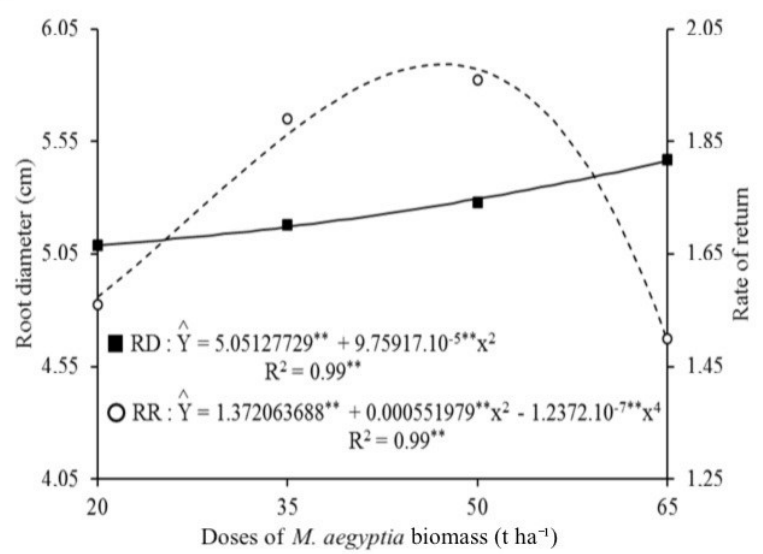

D

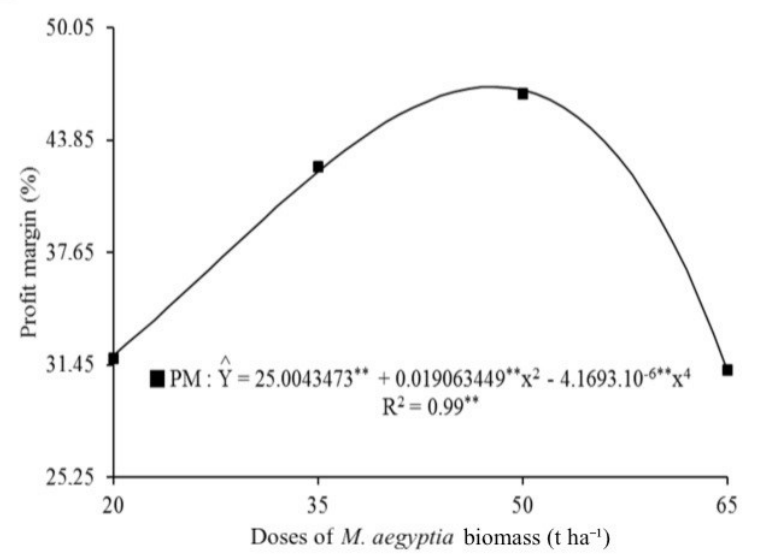

Figure 4. Productivity of scrap roots and dry mass of roots (A), root diameter and rate of return (B), gross and net incomes (C) and profit margin (D) of radish for different doses of M. aegyptia incorporated into the soil. 
Regarding DMR, this variable represents the sum of nutritional constituents, with the exception of water, in relation to crop productivity. Therefore, it is assumed that the value determined for DMR for the dose $60.38 \mathrm{t} \mathrm{ha}^{-1}$ of green manure incorporated into the soil, with a commercial productivity of $7.21 \mathrm{t} \mathrm{ha}^{-1}$, represents a higher dose of minerals and vitamins.

An increase was also observed for the economic indicators rate of return, gross and net incomes and the profit margin with increasing doses of green manure, obtaining a maximum of 1.99 , $23,680.64$ and $11,955.46 \mathrm{RS} \mathrm{ha}^{-1}$ and $46.80 \%$ for the doses of $47.23,51.12,46.00$ and $47.81 \mathrm{tha}^{-1}$ of green manure (Figures 4B, C, D).

The increase in the values of the economic indicators is attributed to the yield of the crops through the efficient use of environmental resources.

Studying the cropping periods for each dose of $M$. aegyptia regarding plant height and fresh and dry mass of radish shoots, except for the dose of $35 \mathrm{t} \mathrm{ha}^{-1}$, significant differences in plant height were registered for the second and third periods, standing out from the first period at the doses of 20 and $50 \mathrm{tha}^{-1}$ and in the dose of $65 \mathrm{t} \mathrm{ha}^{-1}$ the mean of third period highlighting from the others.

Fresh shoot mass in the second and third period was higher than in the first period, except for the dose of $65 \mathrm{tha}^{-1}$, where the average values of the third period was highest. A different behaviour was observed for the dry mass of shoots, where the means of the third period stood out from the others for all green manure doses. Significant differences in root diameter, total and commercial productivity of roots, productivity of scrap roots and dry mass of roots were observed, with the highest values for the third period (Table 5).

Table 5. Plant height (PH), fresh (FMS) and dry mass of shoots (DMS), root diameter (RD), total (TPR) and commercial (CPR) productivity of roots, productivity of scrap roots (PSR), dry mass of roots (DMR), rate of return (RR), gross income (GI), net income (NI), and profit margin (PM) of radish at different doses of $M$. aegyptia incorporated into the soil and in different cropping periods.

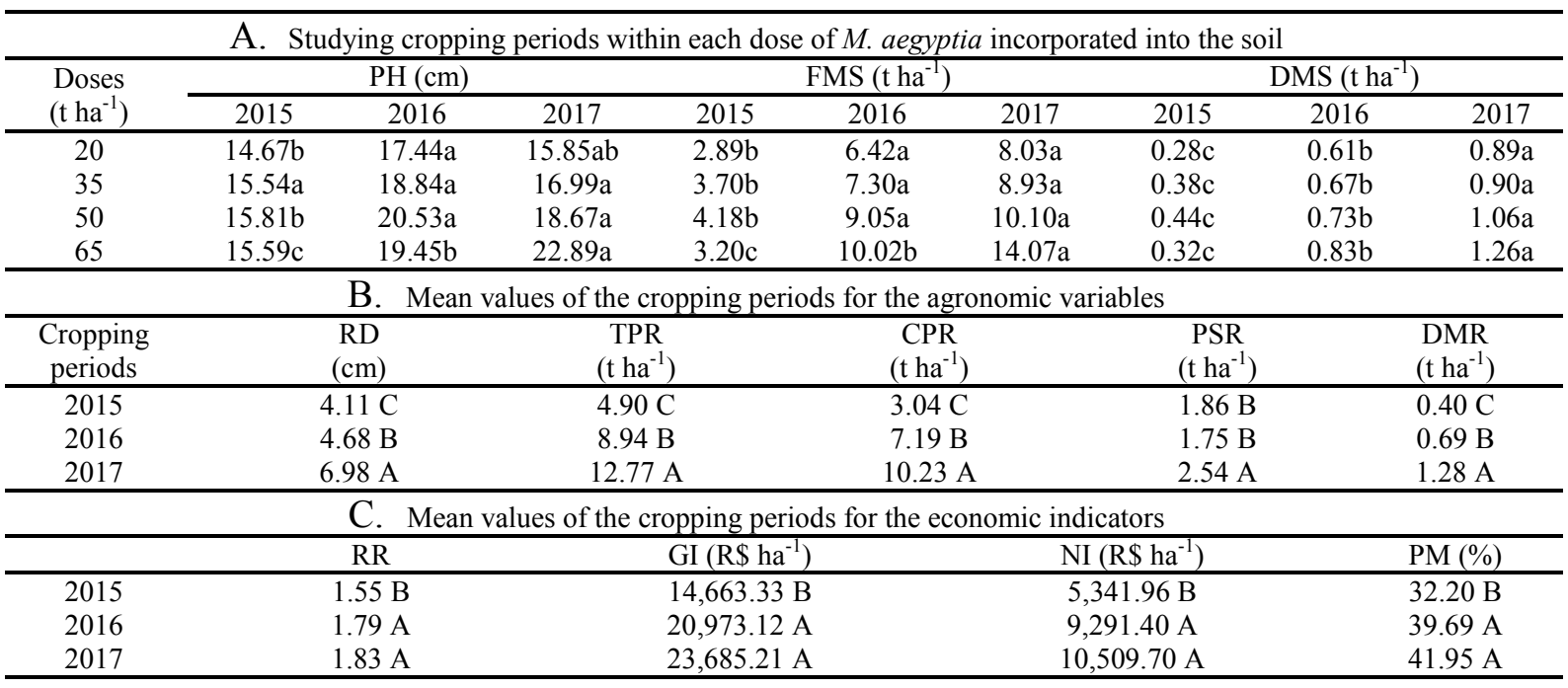

*Means followed by the same lowercase or uppercase letter in the row or column, respectively, do not differ from each other by the Tukey test at the $5 \%$ probability level.

Table 5 shows the significant differences for the mean values of the economic indicators among the cropping periods, with the second and third period standing out from the first period.

Based on the values for each cropping period, we infer that the behaviour of the agronomic variables of radish can be related in part to soil fertility (Table 2), in addition to the availability of nutrients released by the green manure (Table 3 ), as well as by the synchrony in which these elements are released and absorbed by the plant during the crop cycle (BEZERRA NETO et al., 2014).

The differences among the periods are associated with the different yields of the crop obtained in the cropping periods and the price paid to the producer at the market level in the region in the years 2015, 2016 and 2017.

\section{CONCLUSIONS}

Maximum agronomic efficiency was reached with a commercial root productivity of $7.86 \mathrm{t} \mathrm{ha}^{-1}$, when green manure was added at a dose of $49.29 t$ $\mathrm{ha}^{-1}$. Maximum economic efficiency was obtained with a net income of $11,955.46 \mathrm{R} \$ \mathrm{ha}^{-1}$, when $46.00 \mathrm{t}$ 
$\mathrm{ha}^{-1}$ of green manure were added to the soil. The best agronomic results were obtained in the third cropping period, while the best economic results were achieved in the second and third cropping periods. The use of M. aegyptia as green manure is economically viable for the production of radish in the semi-arid region of Northeast Brazil.

\section{ACKNOWLEDGEMENTS}

We thank the Coordenação de Aperfeiçoamento de Pessoal de Nível Superior (CAPES) (CAPES) for financial support and the research group of the Department of Agronomic and Forestry Sciences of the Universidade Federal do Semi-Árido (UFERSA) for the development of technologies for growing vegetables on family farms.

\section{REFERENCES}

ALCÂNTARA, F. A. et al. Adubação verde na recuperação da fertilidade de um Latossolo Vermelho-Escuro degradado. Pesquisa Agropecuária Brasileira, 35: 277-288, 2000.

ALLEN, R. G. et al. Crop evapotranspiration: Guidelines for computing crop water requirements. Rome: FAO. Irrigation and Drainage Paper, 1998. 300 p.

ALVARES, C. A. et al. Koppen's climate classification map for Brazil. Meteorologische Zeitschrift, 22: 711-728, 2014.

BATISTA, M. A. V. et al. Atributos microbiológicos do solo e produtividade de rabanete influenciados pelo uso de espécies espontâneas. Horticultura Brasileira, 31: 587-594, 2013.

BATISTA, T. M. V. et al. Bio-agro-economic returns from carrot and salad rocket as intercrops using hairy woodrose as green manure in a semi-arid region of Brazil. Ecological Indicators, 67: 458$465,2016$.

BELTRÃO, N. E. M. et al. Comparação entre indicadores agroeconômicos de avaliação de agroecossistemas consorciados e solteiros envolvendo algodão "upland" e feijão "caupi". Boletim de pesquisa, 15: 1-21, 1984.

BEZERRA NETO, F. et al. Desempenho agronômico da alface em diferentes quantidades e tempos de decomposição de jitirana verde. Revista Brasileira de Ciências Agrárias, 6: 236-242, 2011.
BEZERRA NETO, F. et al. Otimização agroeconômica da cenoura fertilizada com diferentes doses de jitirana. Revista Ciência Agronômica, 45: 305-311, 2014.

CASTRO, B. F. et al. Radish production function of the potassium fertilization and different nitrogen sources. Revista de Ciências Agrárias, 39: 455$472,2016$.

EMPRESA BRASILEIRA DE PESQUISA AGROPECUÁRIA - EMBRAPA. Manual de análises químicas de solos, plantas e fertilizantes. 2. ed. Brasília: Embrapa Informação Tecnológica, 2009. 627 p.

FERREIRA, D. F. Sisvar - Sistema de análise de variância para dados balanceados. Ciência e Agrotecnologia, 35: 1039-1042, 2011.

ISLAM, M. M. A. et al. Effects of organic manure and chemical fertilizers on crops in the radish-stem amaranth Indian spinach cropping pattern in homestead area. Australian Journal of Crop Science, 5: 1370-1378, 2011.

JANDEL SCIENTIFIC. Table Curve: Curve fitting software. Corte Madera, CA: Jandel Scientific, 1991. 280 p.

LINHARES, P. C. A. et al. Polycultures of coriander, carrot, and arugula in strip-intercropping system. Revista Caatinga, 30: 622-632, 2017.

NUNES, R. L. C. et al. Agroeconomic responsiveness of radish associations with cowpea in the presence of different amounts of Calotropis procera, spatial arrangements and agricultural crops. Ciência e Agrotecnologia, 42: 350-363, 2018.

OLIARI, I. C. R. et al. Effect of restriction of solar radiation and increases of temperature on the growth of radish plants. Applied Research \& Agrotechnology, 3: 85-96, 2010.

OLIVEIRA, G. Q. et al. Aspectos produtivos do rabanete em função da adubação nitrogenada com e sem hidrogel. Journal of Agronomic Sciences, 3: 89-100, 2014

OLIVEIRA, L. J. et al. Viability of polycultures of arugula-carrot-coriander fertilized with hairy woodrose under different population densities. Revista Brasileira Engenharia Agrícola Ambiental, 21: 611-617, 2017.

PEREIRA, M. F. S. et al. Productive performance of cowpea-radish intercropping under different amounts of rooster tree biomass incorporated into the soil. Revista Brasileira de Engenharia Agrícola e 
Ambiental, 20: 965-971, 2016.

RÊGO, L. G. S. et al. Pedogenesis and soil classification of an experimental farm in Mossoró, state of Rio Grande do Norte, Brazil. Revista Caatinga, 29: 1036-1042, 2016.

SILVA, A. F. A. et al. Rentabilidade do rabanete adubado com flor-de-seda em duas épocas de cultivo no semiárido de Pernambuco. Revista Brasileira de Ciências Agrárias, 58: 198-207, 2016.

SILVA, D. J.; QUEIROZ, A. C. Análise de alimentos: métodos químicos e biológicos. 3.ed. Viçosa, MG: UFV, 2002. 235 p.

SOUSA, D. M. et al. Agro-economic performance of the association of beet with green cowpea in different amounts of hairy woodrose. Revista Brasileira de Engenharia Agrícola e Ambiental, 22: 194-199, 2018.

SOUZA, A. R. E. et al. Agronomic performance of carrot fertilized with roostertree [Calotropis procera (Ait.) R. Br.] in two growing seasons. Bioscience Journal, 33: 1401-1411, 2017.

VIEIRA, F. A. et al. Technical-economic efficiency of the yield of green grains of cowpea fertilized with roostertree. Revista Caatinga, 31: 504-510, 2018. 